This item was submitted to Loughborough's Research Repository by the author.

Items in Figshare are protected by copyright, with all rights reserved, unless otherwise indicated.

\title{
Services networks: concept and research agenda
}

PLEASE CITE THE PUBLISHED VERSION

http://dx.doi.org/10.1016/j.indmarman.2012.11.013

\section{PUBLISHER}

(c) Elsevier Inc.

\section{VERSION}

AM (Accepted Manuscript)

LICENCE

CC BY-NC-ND 4.0

\section{REPOSITORY RECORD}

Henneberg, Stephan C., Thorsten Gruber, and Peter Naude. 2019. "Services Networks: Concept and Research Agenda". figshare. https://hdl.handle.net/2134/11916. 
This item was submitted to Loughborough's Institutional Repository (https://dspace.lboro.ac.uk/) by the author and is made available under the following Creative Commons Licence conditions.

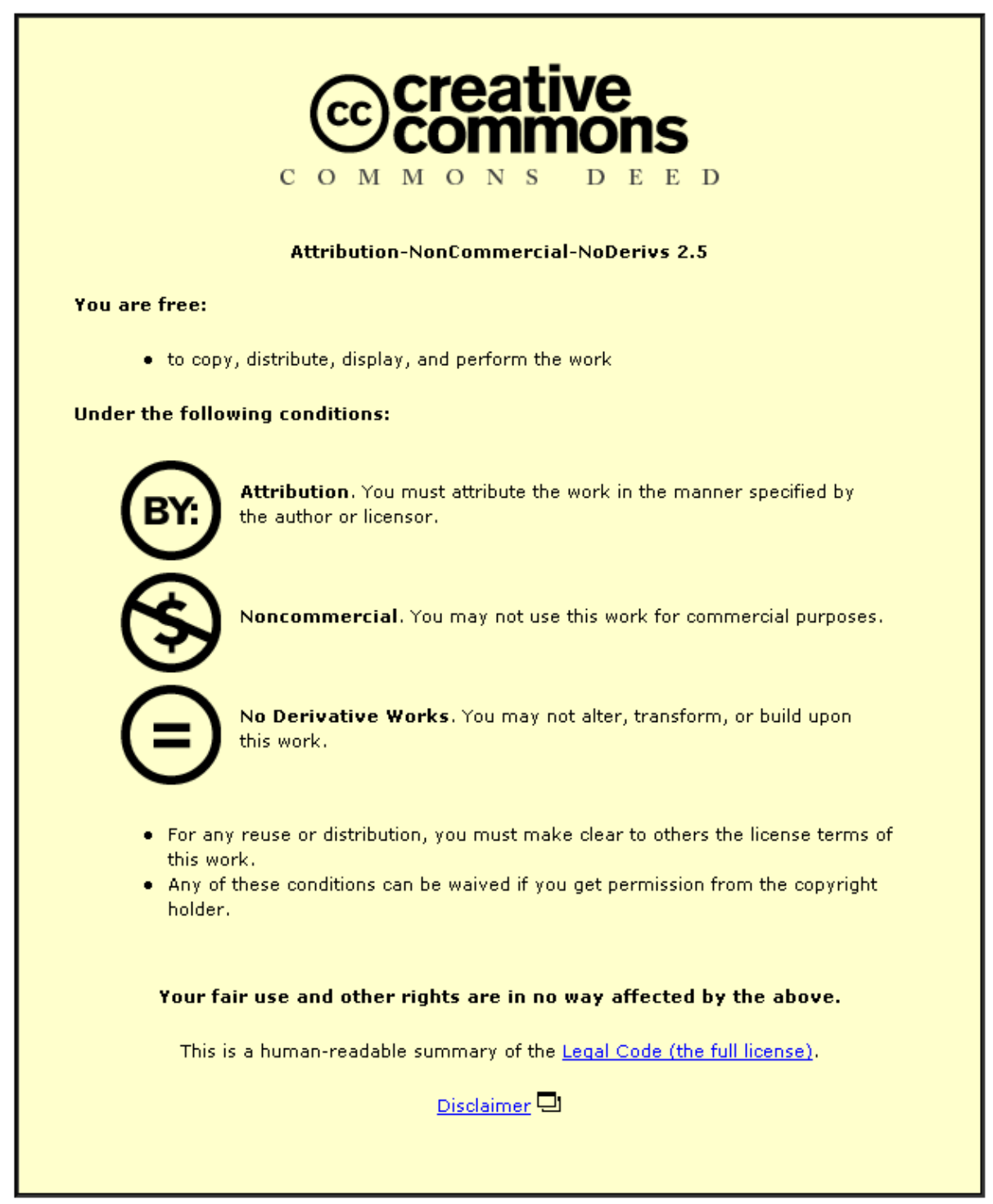

For the full text of this licence, please go to: http://creativecommons.org/licenses/by-nc-nd/2.5/ 


\title{
Services Networks: Concept and Research Agenda
}

\author{
Stephan C. Henneberg*) \\ Thorsten Gruber \\ Peter Naudé \\ all at \\ mIMP Research Group \\ Manchester Business School \\ University of Manchester \\ Booth Street West \\ Manchester M15 6PB, UK
}

Industrial Marketing Management

Special Issue on Services Networks

November 2012

*) Corresponding Author 


\section{Services Networks: Concept and Research Agenda}

\section{Introduction}

Services today dominate most developed economies in the world (Spohrer \& Maglio, 2008; Ostrom et al. 2010). This is true not only for business-toconsumer but also for business-to-business marketing as even countries with a traditional main focus on manufacturing are witnessing significant service growth (Ostrom et al. 2010). Tangible product-dominated interactions are still important but are becoming less so, or are becoming integrated with services issues (Rust and Chung, 2006). In this context, we do not use the concept of services as an all-encompassing category, as is done for example in the socalled service-dominant logic (SDL) interpretation (see Ford 2011 for a comparison of the SDL view and the approach used in our argument; see also the Ford and Mouzas article in this special issue). However, while these trends of increasing service importance are now well established in the consumer area, research on services in the business marketing literature has not yet received the same importance (Rust and Chung, 2006); goods-based interactions in industrial settings are still providing the contextual setting for most research studies (Ford et al., 2003; Ford 2011).

B2B services are still an underrepresented research topic, with Ostrom et al. (2010) calling for more work in this area. Similarly, Kunz and Hogreve (2011), who used a citation-based approach to reveal promising future research trends in services marketing, expect research on business-to-business services in 
general and service infusion in particular to "be of great interest in the near future" (p. 244).

Furthermore, many concepts and theories in business marketing emanate from studies of manufacturing businesses (e.g. see the history of the Industrial Marketing and Purchasing Group; Ford and Hakansson, 2006; Hakansson et al, 2009). There exists, therefore, a potential issue with regard to the applicability of such goods-based theories and concepts in the context of services. Thus, research in (business) marketing is still not mirroring the importance of service interaction as exemplified in most economic situations.

The concept of business networks provides the starting point for a related issue: business interactions are often seen as embedded in a wider environment of multiple actors with indirect and direct influences on a focal actor or a focal relationship (Ford et al., 2003). Thus, the business network, which is based on aspects of connectivity and interdependence, has become an important explanatory concept, particularly in the IMP Group. In the context of our argument, our understanding of business networks is informed by the Industrial Network Approach (INA) and the Interaction Model of the IMP Group (Hakansson and Ford, 2002; Ford et al., 2003; interestingly enough, this perspective was not mentioned in a special issue on services networks previously published; Scott and Laws, 2010). Thus, a network is characterized by business relationships of actor ties, resource bonds, and activity links, which are embedded in a network of other, interdependent relationships (Hakansson and Snehota, 1995; Hakansson et al., 2009). As such, constellations of 
actor/activity/resource interlinkages are formed, which characterize the overall business network. Such an understanding broadens the view of business marketing beyond managerial activities by isolated actors. Rather, business marketing as part of the INA relates to complex systems (networks) where interaction - not managerial action - becomes the main research object (Hakansson et al., 2009).

However, in line with general trends on research in the services area in business-to-business settings, studies on business networks also seem to focus mostly on industrial networks. This issue was highlighted by Rust and Chung (2006). Therefore, our special issue in Industrial Marketing Management takes its starting point from their observation and call for future research in this area, and tries to understand different aspects of the concept of services networks, i.e. specific systemic structures which are based on interactions focusing on services (Scott and Laws, 2010). In order to do this, we first start by trying to present pertinent aspects of the extant literature, with a specific focus on the concept of services networks. Based on these findings, we secondly outline a possible understanding of the concept of services networks by delineating different layers. Thirdly, we introduce the articles, which make up this special issue on services networks, and lastly, we discuss a possible research agenda. For this purpose, we also juxtapose our services network concept with the topics of the presented articles.

\section{Services Networks}


Service marketing traditionally focuses on investigating service encounters between individual service providers and customers (Tax et al. 2011). This focus on service provider-customer dyads, however, does not reflect the true complexity of all service relationships (Morgan et al. 2007). Several services require a whole network of service providers to offer the service to the customer. Rust and Chung (2006) give the example of an airline flight that involves several different service providers such as airlines, food caterers, security staff, refueling personnel and air traffic controllers. Some of these providers may have conflicting interests which could then have a negative effect on customer satisfaction.

Services network is astonishingly enough not a term that is often used in research in business marketing, compared to service relationships (Rust and Chung, 2006). Research on services networks is still "in its infancy" and focuses predominately on B2C contexts (Morgan et al. 2007, p. 375). Services networks research is also one of the 10 overarching research priorities identified by Ostrom et al. (2010) in their award winning article.

While references to business networks are countless, services networks have not yet been treated conceptually with the same detail (Scott and Laws, 2010). An initial look at the literature reveals that issues of services networks are covered in two main strands of literature: that of business marketing, and of services systems/service science. According to Agarwal and Selen (2011), the terms "services networks" and "service systems" are sometimes also used interchangeably. 


\subsection{Business marketing literature}

While issues of service delivery networks or service logistics networks are discussed in business marketing, and also the related supply chain management literature, this is most often the case in terms of operations, production and/or ICT systems. Although such literature provides important insights, e.g. with regard to how embeddedness and interdependence affect service innovation activities (Eisingerich et al., 2009; Agarwal and Selen, 2011; Hsue et al., 2010), it often focuses on isolated (dyadic) business relationships and tends not to cover aspect of services networks per se. Unfortunately, the business marketing literature does not provide further conceptual clarification. If services networks are researched, this is often done without providing a clear definition and discussion of the concept itself (Leek and Canning, 2011; Zolkiewski, 2011). For example, in the context of demand and capacity balancing activities in service provisions, Pullman and Thompson (2003) use a service network context without clarifying specifically what this entails (their understanding of a network relates more to connected actors, or clusters of activities). Similarly, service network concepts are used interchangeably with service value chain models (Hammerschmidt et al., 2012), which is incommensurable with a network understanding based on INA (Ford et al., 2003). Similar approaches relate to orchestrated service networks (Evanschitzky, 2007), thereby implying a focal net perspective (Moller and Halinen, 1999; Moller et al., 2005) as the foundation for their reasoning. Furthermore, an "exchange of resources between the participating network partners" (Evanschitzky, 2007, p. 351) is stipulated, 
therefore focusing only on direct interaction relationships (Hakansson et al., 2009). The services network definition most compatible with the INA perspective was provided in a working paper by Morgan and Tax (2004); who define services networks as "two or more entities connected formally or informally which directly provide a range of resources and activities that create value and help customers solve short- or long-term problems."

Alternatively, the focus in the business marketing literature is on networks in the study of services, without necessarily clarifying what the specifics of a services network are (Scott \& Laws, 2010). An exception is Morgan et al., (2007) who refer specifically to Morgan and Tax's (2004) definition of services networks in the context of service branding in business relationships and networks (although they also stipulate that each entity in the network is directly related to end-customers). Furthermore, the network concept is additionally often used as a new organizational form (Jones et al., 1997), which is applied to service-related phenomena (e.g. Koz and Lewin, 1999).

\subsection{Services systems/science literature}

The services systems and services science literature provides clearer definitions of the phenomenon at hand, albeit applying a different perspective. For example, Maglio and Spohrer (2008) define service systems as "value-cocreation configurations of people, technology, value propositions connecting internal and external service systems, and shared information" (p. 18). Similarly, Maglio et al. (2009) define service systems as "a configuration of people, technologies, and other resources that interact with other service systems to 
create mutual value." (395). As such, this definition provides a network perspective, which also includes the interplay between actor-internal and external aspects. However, it is more restricting than the network interpretation as used in the INA: only value-co-creation relationships are included, and specific resources are the main focus. Similarly restricting from an INA perspective is Razo-Zapata et al. (2012, p. 47): “ $A$ Service Network is a team of individuals who establish relationships among homogeneous peers to provide a specific service" (emphasis in original), as this focuses exclusively on the individual level.

Within this strand of research, shifts in the system (i.e. the business network), most often seen as linked to the results of service innovation, provide a major focus for current and future studies (Spohrer and Maglio, 2008). In this research strand, aspects of "partner ecosystems" (Razo-Zapata et al, 2012, p. 45), which provide various services around a core offering, as is the case with Microsoft, are often analyzed.

The focus in the literature on service innovation and networks is not surprising as service companies need to regularly renew themselves and have to develop strategies for new service development. A common way is to co-opt resources from outside by including existing or new partners, suppliers and customers who bring resources into the development of new services in fruitful ways. User contribution systems are now being developed in many companies and the business network is re-created. The mobilization of the "collective intelligence of outsiders" has become a strategically focused area. Pisano and 
Verganti (2008, p. 78) argue that "the leaders in innovation will be those who figure out the best ways to leverage a network of outsiders". Especially small and medium sized enterprises (SMEs) that lack internal resources for innovation can benefit from co-operating with external partners (Teece, 1986). These networks include stakeholders such customers, suppliers, and research institutions (Mohannak, 2007). Networks are especially important in complex market conditions that change quickly (Jones, Hesterly, and Borgatti, 1997).

\section{Concept of Services Networks}

For the purpose of this special issue on services networks in Industrial Marketing Management, an initial concept of services networks needs to be provided, as the current conceptualization and operationalization of services networks in the business marketing literature is arguably too vague, while the services systems/services science literature provides interesting starting points but is too restricted to operational and process issues around service innovations.

We believe it is helpful to delineate different layers or dimensions of services networks (see figure 1). First, a micro dimension of services networks relates to the use of services in interactions. Such interactions can be based on manufacturing, i.e. product-based exchanges. However, they may be further infused with services (either product-related, or customer-related ones) (Mathieu, 2001; Eggert et al, 2011). The systemic aspects of such infusion processes, e.g. how third parties are used to provide additional services, allow 
for an understanding of first order services networks. Secondly, if customerrelated services as part of product-based exchanges take over, and solutions are formed (i.e. an amalgamated proposition to the customer of product and service configurations, which the seller provides, either alone or in cooperation with other parties) (Tuli et al, 2007; Windahl and Lakemond, 2006), then new constellations of resources, actors, and activities develop, i.e. second order services networks. For both first and second order services networks, tangible and intangible aspects (i.e. product and services) are of primary importance, although in different constellations. Finally business networks can be formed around a knowledge or information-based core, such as education or industries which are based around knowledge-intensive business services (KIBS) (Muller and Zenker, 2001). In this case, tangible aspects become secondary, and the network core is linked to the offering of the services. This represents a third order services network. The three introduced layers represent different intensities of possible service network constellations. As will be clear when the papers in this Special Issue are read, they all tend to focus almost exclusively on the migration form First to Second Order Service Networks, indicating perhaps that the time is right to shift our research focus to understanding the more complex but emergent Third Order Networks.

Insert figure 1 about here 


\section{Articles in the Special Issue}

This Special Issue on Services Networks is made of six research papers which provide different perspectives on the phenomenon in question. The first paper, by Ford and Mouzas, provides a useful starting point to our attempts to understand the nature of the evolution of business services in that it examines the a case study through three different lenses: the conventional Marketing Management Approach, the Service-Dominant Logic of Vargo and Lusch (2004, 2011), and the IMP Group's Approach (Håkansson, 1982; Ford, 2011). Their work is grounded in a case study on the technological development in the UK's pre-prepared chilled ready meals market - one that has traditionally operated at what we would regard as a First Order Service Network (Figure 1). The authors show how it has evolved into a Second Order Network, as the market has developed increasing levels of service surrounding the original product offering, leading to increased levels of activity in the network that became increasingly specialized, the resources were developed along a more clearly defined path, and the actors tended to co-evolve. They develop their argument further by examining value within the service network, arguing that value can be viewed as being developed at four different levels, which in turn are exemplified based on two additional case studies.

This is followed by the paper by Kowalkowski, Witell and Gustafsson, in which the authors show how firms can manage the transition from First Order to Second Order Service Networks. Based on a sample of thirteen SMEs in the Nordics, the authors argue that there is no one predefined route to seeking to 
offer increased service infusion. Although they are often hampered by the common problem of a relative lack of access to the requisite resources, these firms have not all followed specific phases during their transition. Instead, the results point to the argument that that the transition through the different levels in Figure 1 can be achieved by firms adopting any one of nine different generic value constellations.

The next paper has a similar theme to the one that precedes it. Gebauer, Paiola and Saccani also examine the characteristics of service networks as companies develop from offering products to higher levels of service infusion. The two papers are nicely juxtaposed in that the authors here, also based on case studies, identify four rather than nine different types of Service Networks. The authors argue here that what determines which of the four possible variants is chosen is contingent upon a set of dynamic capabilities to initiate a specific network formation, plus operational capabilities that allow the focal companies to develop, integrate and deliver the services. These two papers, we believe, together offer an excellent starting point for future research to further develop our understanding in this area.

Generally, increasing the level of service offering is assumed to be a 'good' thing. But little is known of how customers value this change in strategy on the part of the suppliers. The paper by Jaakkola and Hakanen sets out to probe this issue by examining two different service networks, different in the sense that one of them, an Industrial Solution Network, is what we would categorize as being a First Order Service Network, while the other, a Marketing Solution 
Network, is closer to what we would regard as a Third Order Service Network. Both the benefits but also the sacrifices of the integrated solution network are identified, with the extent to which value was perceived being dependent on the extent of resource integration and interaction processes between the parties involved.

In a similar vein, trying to develop our understanding of the way(s) in which manufacturing firms can improve their product offering by infusing additional service elements, Spring and Araujo are informed by the earlier work of Penrose (1959) and of Chase's (1988) notion of the 'service factory' to understand better the different ways in which this transformation can occur. Based on an examination of three different projects in a (UK-based) focal firm, the authors propose a model showing how manufacturing forms can develop their service offering.

The sixth and final paper in our Special Issue offer a very different perspective. In the only quantitative paper in the set, Kohtomäki, Partanen and Möller argue that there is very little evidence as to the impact that suppliers' R\&D services have on profitability at the relationship level. Based on a sample of 91 supplier-customer relationships in the Finish manufacturing sector, propose a direct link between the extent of R\&D services offered by suppliers and the suppliers' profit performance in that relationship. They test too the direct and moderating effects of relational capital. Interestingly, their results point to there being no direct effect on the relationship profitability by the 
provision of these services. Relational capital, on the other hand, is shown to have both a direct and a moderating effect.

\section{Research Agenda}

In this section we identify a number of issues that we believe will provide fruitful avenues for researchers in the near future. As such, a tentative research agenda is provided. At the heart of our thinking is the belief that our research efforts should and will focus increasingly on what we have termed Third Order Services Networks - those where the core of the offering revolves around services themselves and not some service-infused product offering.

\subsection{Strong Ties vs Weak Ties - The Old Debate}

According to Granovetter (1985), companies and thus service systems are embedded in networks of professional and social relationships with other actors. There are two views in the literature of how these networks are structured and how they may impact a company's ability for adaptive change: Granovetter (1973) distinguishes between weak ties (contacts do not know each other well) and strong ties (family and close friends). Strong ties demand more maintenance than weak ties, are fewer in number, and the actors tend to have similar views and information.

Companies with strong ties between them interact frequently, learn from each other and develop the social side of the economic exchange (Larson, 1992). However, companies with strong ties are in danger of being locked in a limited set of ossified relationships, and may be unable to profit from new 
opportunities and potential partners outside their current network (Capaldo, 2007).

Hite and Hesterly (2001) suggest that companies have to strategically align and adapt their networks to gain access to the resources that they need, in line with suggestions by the resource-dependency theory (Pfeffer and Salancik, 1978). They posit that networks of companies in the emergence stage consist mainly of strong, socially embedded ties that mainly result from pre-existing relationships (family, friends, long-held sources). The goal of companies during emergence is organizational survival and especially coping with liabilities of being small, new and having only limited access to resources. During early growth, companies build up a track record, increase legitimacy and reputation and their networks then evolve more towards a balance of socially embedded and more diverse, arm's length, and market-like relations. Likewise, Capaldo (2007) suggests that companies should have a dual structure consisting of a core of strong homogeneous ties and a large number of weak heterogeneous ties.

While the topic may at first glance appear somewhat jaded, a pertinent question still remains to be answered: are strong ties or weak ties better for services networks in general and service innovativeness in particular? Further research is needed to tease out the complexities. Evidence exists suggesting that the success of B2B service firms depends on finding the appropriate balance between strong and weak ties, and also that the importance of 
strong/weak ties may depend on the life cycle stage of the services network's core processes (Eisingerich and Bell, 2008).

\subsection{The Impact of Network Partner Performance on Focal Firm Evaluations}

Morgan et al. (2007) argue that in a B2B context, companies operating in strategic or hub-and-spoke networks would tend to outsource after-sales service and support to other parties, and that the performance of these service providers could then affect the evaluation of the hub company. As a consequence, we believe that more research is necessary to investigate how the activities and the performance of a services network partner influences the customer's evaluation of the focal company (the hub). This relates to issues around network embeddedness (Hsueh et al., 2010). Morgan et al. (2007) present a conceptual framework with 'partner firm performance' as the independent variable, 'customer evaluation of focal firm"'as dependent variable and 'focal firm-customer relationship strength', 'focal brand strength', 'importance of partner service' and 'focal firm-partner firm relationship strength' as moderators. Further research could test this model empirically in different B2B service settings. An adjacent area is that of how performance should be measured not at the company level, but across a services network how do we determine whether network A or network B is, according to some pre-defined metric, more optimal in bringing about a result? This raises the issue of how to think about accounting across a network, the subject of a recent book by Håkansson et al. (2010).

\subsection{Service Recovery Networks}


The impact of network partner performance on focal firm evaluation is of particular interest in the case of a service failure: A good example is the YouTube video "United breaks guitars" (http://www.youtube.com/watch?v=5YGc4zOqoz). This video has been watched more than 12.5 million times since it was first uploaded in July 2009 . The video shows a customer, who happens to be a country musician, performing a song in which he complains about baggage handlers at Chicago O’Hare airport destroying his Taylor guitar. He especially criticizes United Airlines for not taking his complaint seriously and for not compensating him for the costs he incurred. The success of the video resulted in a major PR disaster for United Airlines.

A closer look at the video reveals that the complaining customer is blaming United Airlines for a mistake made by one of United's service partners (baggage handlers at Chicago O'Hare who also provide their services to other airlines). It shows the 'danger' of being part of a services network, especially if things go wrong and customers put blame on and demand action from the focal company for mistakes made by network partners.

According to Tax et al. (2011), there is currently scant research addressing the impact of third parties' service failures on other services network parties. Their results point to the fact that network partners have to respond to service failures even if these are caused by another network member. This challenges our current understanding of attribution theory, which postulates that one will only be held accountable for failures for which one is responsible. By contrast, 
in a services network context, "responsibility for recovery [...] is shared" (Tax et al. 2011, p. 24). Focal companies therefore have to either solve the problem themselves, or work together with the service network partner(s) who caused the problem to solve the matter as soon as possible. They have to take responsibility, and finding a quick solution demands relational communication and coordination among services network partners in these service recovery situations.

On this topic, Morgan et al. (2007, p. 373) suggest that further research should investigate "how customers evaluate firms in a B2B service network and how their assessment of the firms co-producing the after-sales service affects their evaluation of the focal (selling) firm." From our network-oriented perspective, however, we would argue that this takes a too restrictive view, one in which firms in their strategic or firm-centric B2B services network all come into direct contact with the customer firm. As the example exemplified above makes clear, the relevant relationships are often indirect.

\subsection{Understanding the Complexity of Service Networks}

The final issue that we see coming to the fore is one that is already represented by some of the papers in this Special Issue: how do services networks develop over time? And indeed, is their just one path to be taken, or are there different routes to the top? (Koza and Lewin, 1999). In a sense this is the same discussion that has been taken by some researchers in the field of international marketing - is the Uppsala model always the right way to go, or should firms sometimes chose another route to going global? As argued 
differently in the papers by Gebauer et al. and also Kowalkowski in this issue, understanding the complexity in form and over time of how services networks develop is crucial to our being able to understand them better.

This understanding is bedeviled by the underlying complexity. As noted by Ramirez (1999), the actors may hold different roles at any one point in time, not only with different counterparts but indeed with the same one. As he notes: “one economic actor 'A' may simultaneously be (i) a supplier to another economic actor ' $B$ ', (ii) as well as a customer of economic actor ' $B$ ', (iii) as well as a competitor of ' $B$ ', (iv) as well as a partner with ' $B$ ' to produce value with and for a third economic actor ' $C$ ', and ( $v$ ) possibly a competitor with 'B's partners. (1999, p. 54).

As noted by Alexander and Jaakkola ((2011), this example illustrates that value co-creation within a services network can and should not be seen through the simple monadic or even dyadic lenses that typify much of what is done in B2B research, but rather as a something that may well take place within a far more complex system of direct and indirect relationships. In searching to understand this complexity better, we would refer readers to the paper of Stabell and Fjeldstad (1998) who see configuring value as being a choice between adopting a chain, shop, or network configuration. Findings similar (or different) aspects in cases of services network configurations represent an important avenue for future research on services networks. 


\section{References}

Agarwal, R. and Selen, W. (2011), "Multi-dimensional Nature of Service Innovation", International Journal of Operations \& Production Management, 31(11), 1164-1192.

Alexander, M. and E. Jaakkola (2011), "Exploring Value Co-creation within Networks: Actor-to-actor Service Provision within a Public Transport Service System", Paper presented at the 27 ${ }^{\text {th }}$ IMP Conference, Sept. 2011, Glasgow.

Chase, R. and Erikson, W. J. (1988), "The Service Factory", The Academy of Management Executive, 11(3), 191-196.

Eggert, A., Hogreve, J., Ulaga, W. and Muenkhoff, E. (2011), “Industrial Services, Production Innovation, and Firm Profitability", Industrial Marketing Management, 40(5), 661-670.

Eisingerich, A. B., Rubera, G. and Seifert, M. (2009), “Managing Service Innovations and Interorganizational Relationships for Firm Performance", Journal of Service Research, 11(4), 344-356.

Evanschitzky, H. (2007), "Market Orientation of Service Networks: Direct and Indirect Effects of Sustained Competitive Advantage", Journal of Strategic Management, 15(4), 349-368.

Ford, I. D. (2011), "IMP and Service-dominant Logic: Divergence, Convergence and Development", Industrial Marketing Management, 40(2), 231-239.

Ford I. D., Gadde, L.-E., Hakansson, H., Lundgren, A., Snehota, I., Turnbull, P. and Wilson, D. (2003), Managing Business Relationships, Chichester: Wiley

Ford, I. D. and Hakansson, H. (2006), "IMP - Some Things Achieved: Much More to Do", European Journal of Marketing, 40(3/4), 248-258.

Håkansson, H., Kraus, K., and Lind, J. (eds.) (2010), Accounting in Networks, Routledge.

Håkansson, H., Ford, I. D., Gadde, L.-E., Snehota, I. and Waluszewski, A. (2009), Business in Networks. Chichester: Wiley.

Håkansson, H. and Ford, I. D. (2002), "How Should Companies Interact in Business Networks?, Journal of Business Research, 55(2), 133-139.

Håkansson, H. and Snehota, I. (1995), Developing Relationships in Business Networks. London: Routledge. 
Håkansson, H. (1982) Industrial Marketing and Purchasing: An Interaction Approach, Chichester, John Wiley.

Hammerschmidt, M., Falk, T. and Staat, M. (2012), "Measuring and Improving the Performance of Health Service Networks", Journal of Service Research, 15(3), 343-357.

Hsueh, J.-T., Lin, N.-P. and Li, H.-C. (2010), "The Effects of Network Embeddedness on Service Innovation Performance", The Service Industries Journal, 30(10), 1723-1736.

Jones, C., Hesterly, W. S. and Borgatti, S. P. (1997), "A General Theory of Network Governance”, Academy of Management Review, 22(4), 911-945.

Koza, M. P. and Lewin, A. Y. (1999), "The Coevolution of Network Alliances: A Longitudinal Analysis of an International Professional Service Network", Organization Science, 10(5), 638-653.

Kunz, W. H. and Hogreve, J. (2011). "Toward a Deeper Understanding of Service Marketing: The Past, the Present, and the Future", International Journal of Research in Marketing, 28(3), 231-247.

Leek, S. and Canning, L. (2011), "Entering and Developing a Service Network", Journal of Services Marketing, 25(1), 58-67.

Maglio, P. P. and Spohrer, J. (2008), "Fundamentals of Service Science”, Journal of the Academy of Marketing Science, 36, 18-20.

Mathieu, V. (2001), "Product Services: From a Service Supporting the Product to a Service Supporting the Client", Journal of Business \& Industrial Marketing, 16(1), 39-61

Moller, K. K. and Halinen, A. (1999), "Business Relationships and Networks: Managerial Challenge of the Network Era", Industrial Marketing Management, 28(5), 413-427.

Moller, K. K., Rajala, A. and Svahn, S. (2005), "Strategic Business Net - Their Type and Management", Journal of Business Research, 58(9), 1274-1284.

Morgan, F. N., Deeter-Schmelz, D. and Moberg, C. R. (2007), “Branding Implications of Partner Firm-Focal Firm Relationships in Business-toBusiness Networks", Journal of Business \& Industrial Marketing, 22(6), 372382.

Morgan, F. N. and Tax. S. S. (2004), "Toward a Theory of Service Delivery Nertworks”, Working Paper, Arizona State University, Phoenix. 
Muller, E. and Zenker, A. (2001), "Business Services as Actors of Knowledge Transformation: The Role of KIBS in Regional and National Innovation Systems", Research Policy, 30(9), 1501-1516.

Ostrom, A. L., Bitner, M. J., Brown, S. W., Burkhard, K. A., Goul, M., Smith-Daniels, V., Demirkan, H., and Rabinovich, E. (2010), "Moving Forward and Making a Difference: Research Priorities for the Science of Service", Journal of Service Research, 13(1), 4-36.

Penrose, E. T. (1959), The Theory of the Growth of the Firm. Oxford: Basil Blackwell.

Pfeffer. J. and Salancik, G. R. (1978), The External Control of Organizations: A Resource Dependence Perspective, New York: Harper \& Row.

Pullman, M. E. and Thompson, G. (2003), "Strategies for Integrating Capacity with Demand in Service Networks", Journal of Service Research, 5(3), 169183.

Ramirez, R. (1999), "Value Co-Production: Intellectual Origins and Implications for Practice and Research, Strategic Management Journal, 20, 49-65.

Razo-Zapata, I. S., de Leenheer, P., Gordijn, J. and Akkermans, H. (2012), "Service Network Approaches", in A. Barros and D. Oberle (eds.), Handbook of Service Description: USDL and its Methods, New York: Springer: 45-74.

Rust, R. T. and Chung, T. S. (2006), "Marketing Models of Service and Relationships", Marketing Science, 25(6), 560-580.

Scott, N. and Laws, E. (2010), "Advances in Service Network Research", The Service Industries Journal, 30(10), 1581-1592.

Spohrer, J. and Maglio, P. P. (2008), "The Emergence of Service Science: Toward Systematic Service Innovations to Accelerate Co-creation of Value", Production and Operations Management, 17(3), 238-246.

Tax, S. S., Smith, A. K. and Chandrashekaran (2011), “Tangled Web or Tidy Knot? Assessing Failure and Recovery in a Service Network". Paper presented at Naples Forum, 14-17th June, 2011.

Tuli, K. R., Kohli, A. K. and Bharadwaj (2007), "Rethinking Customer Solutions: From Product Bundles to Relational Processes", Journal of Marketing, 71(3), 1-17. 
Vargo, S.L. and Lusch, R.F. (2011), "It's all B2B .... and Beyond: Toward a Systems Perspective of the Market', Industrial Marketing Management (40), 181-187.

Vargo, S.L. and Lusch, R.F. (2004), “The Four Service Marketing Myths:

Remnants from a Manufacturing Model, Journal of Service Research, 6(4) 324-335.

Windahl, C. and Lakemond, N. (2006), "Developing Integrated Solutions: The Importance of Relationships Within the Network", Industrial Marketing Management, 35, 806-818.

Zolkiewski, J. (2011), "Value, Power, and Health Care Services in the UK: A business-to-Business Services Network Perspective", Journal of Marketing Management, 27(3/4), 424-448. 


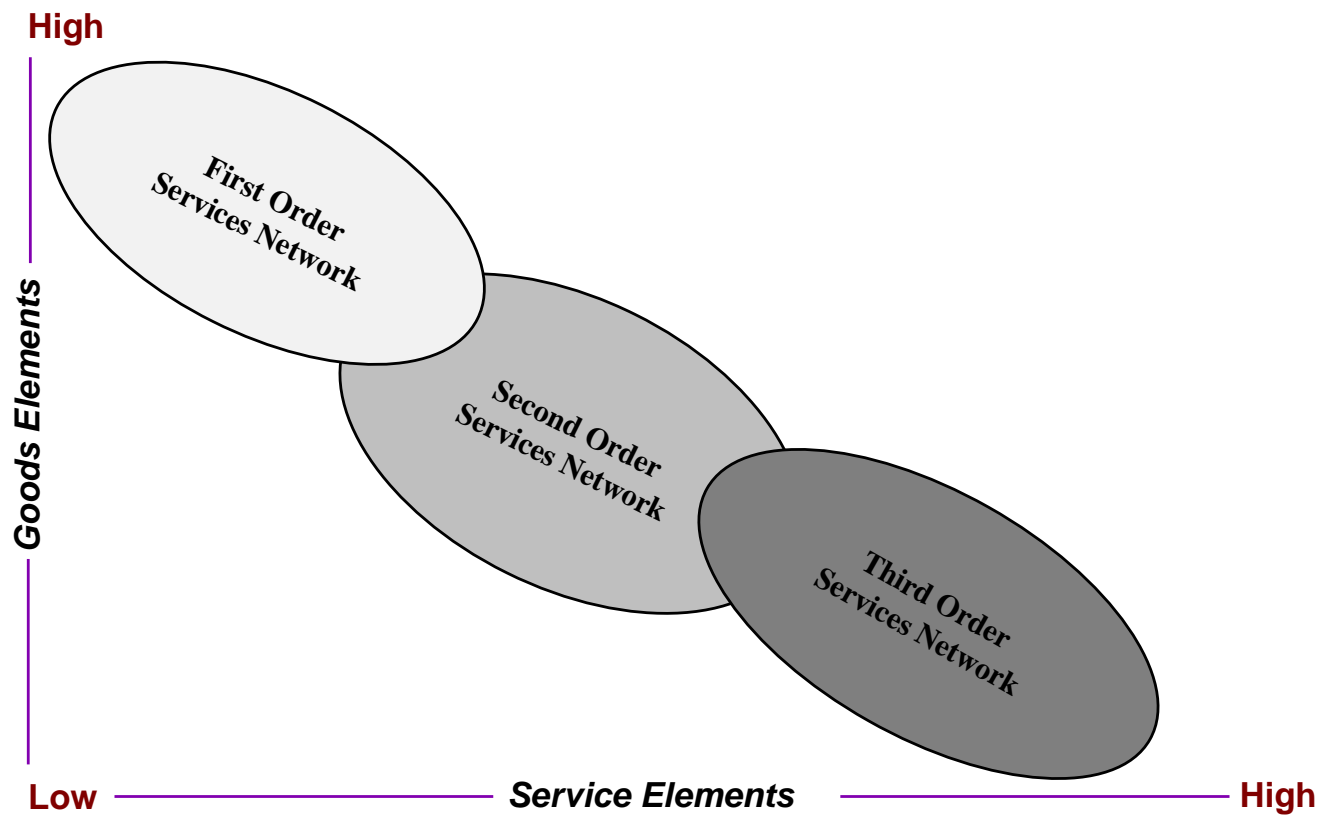

Figure 1: Services Network layers 